\title{
Air-stable, recyclable, and time-efficient diphenylphosphinite cellulose-supported palladium nanoparticles as a catalyst for Suzuki-Miyaura reactions
}

\author{
Qingwei Du and Yiqun $\mathrm{Li}^{*}$
}

Open Access

\author{
Full Research Paper \\ Address: \\ Department of Chemistry, Jinan University, 510632 Guangzhou, \\ China \\ Email: \\ Yiqun Li* - tlyq@jnu.edu.cn \\ * Corresponding author \\ Keywords: \\ diphenylphosphinite cellulose; heterogeneous catalysis; \\ nanopalladium; polymer-supported catalyst; Suzuki-Miyaura reaction
}

Beilstein J. Org. Chem. 2011, 7, 378-385.

doi:10.3762/bjoc.7.48

Received: 24 January 2011

Accepted: 17 March 2011

Published: 30 March 2011

Associate Editor: I. Marek

() $2011 \mathrm{Du}$ and Li; licensee Beilstein-Institut.

License and terms: see end of document.

\begin{abstract}
A diphenylphosphinite cellulose palladium complex $\left(\mathrm{Cell}-\mathrm{OPPh}_{2}-\mathrm{Pd}^{0}\right)$ was found to be a highly efficient heterogeneous catalyst for the Suzuki-Miyaura reaction. The products were obtained in good to excellent yield under mild reaction conditions. Moreover, the catalyst could be easily recovered by simple filtration and reused for at least 6 cycles without losing its activity.
\end{abstract}

\section{Introduction}

The formation of $\mathrm{C}_{\mathrm{sp} 2}-\mathrm{C}_{\mathrm{sp} 2}$ bonds has long remained a difficult task until the development of the Suzuki-Miyaura palladiumcatalyzed reaction [1-3]. The palladium-catalyzed Suzuki crosscoupling reaction of aryl halides with arylboronic acids is one of the most powerful tools for the preparation of unsymmetrical biaryl compounds [4] and has been applied to many areas, including pharmaceuticals, herbicides, and natural products, as well as in the fields of engineering materials, such as conducting polymers, molecular wires, liquid crystals and synthesis of ligands $[5,6]$. In the past few years, many efficient and selective catalytic systems have been developed for the reaction. A considerable number of homogenous palladium catalysts have been used to obtain high yields of a desired product [7-9], for example, phosphorus ligands [10-12], N-heterocyclic carbenes [13-15], P,O-based ligands [16], bis(thiourea) ligands [17], and thiosemicarbazone [18], etc. However, the separation of the catalyst and ligands from the final product is problematic. In this regard, studies on heterogeneous catalysts have drawn much attention because they can be easily separated and recovered [19-22]. Recently, numerous solid-supported palladium catalysts have been reported which can be used under mild and/ or environmentally benign reaction conditions. These supported 
catalysts were prepared by immobilizing palladium(II) on supported ligands [23-25] or palladium(0) nanoparticles on various solid supports [26-31] (polystyrene [26], silica [27], cellulose [28], corn starch [29], polymethyl methacrylate [30] and others [31]). In addition, cellulose as efficient support for $\mathrm{Pd}$ nanoparticles in other cross-coupling and related reactions is also widely used [32-34].

Herein, we report the synthesis of a novel diphenylphosphinite cellulose palladium complex $\left(\mathrm{Cell}-\mathrm{OPPh}_{2}-\mathrm{Pd}^{0}\right)$ by a simple procedure from diphenylphosphinite funtionalized cellulose $\left(\mathrm{Cell}-\mathrm{OPPh}_{2}\right)$ and $\mathrm{PdCl}_{2}$ in ethanol solution [35-44]. This class of supported palladium catalysts would solve the basic problems of homogeneous catalysts, i.e., the separation and recycling of the catalysts. This palladium complex catalyst also has the advantage of avoiding contamination of the products by residue ligand and metal. Moreover, it showed excellent catalytic activity in the Suzuki-Miyaura coupling reaction of various aryl haildes bearing electron-withdrawing and/or electron-donating groups.

\section{Results and Discussion}

\section{Synthesis and characterization of} Cell-OPPh ${ }_{2}$ and Cell-OPPh ${ }_{2}-\mathrm{Pd}^{0}$

It is well known that nanopalladium shows unique reactivity in various organic reactions. However, it is very difficult to use the nanopalladium as practical catalyst because of its tendency to agglomerate and its sensitivity to air and moisture. The Cell- $\mathrm{OPPh}_{2}-\mathrm{Pd}^{0}$ catalyst was prepared with diphenylphosphinite cellulose and palladium dichloride in ethanol (Scheme 1). The as-prepared Cell- $\mathrm{OPPh}_{2}-\mathrm{Pd}^{0}$ catalyst was characterized by inductively coupled plasma-atomic emission spectrometry (ICP-AES), Fourier transform infrared spectroscopy (FTIR), $\mathrm{X}$-ray diffraction (XRD), thermogravimetric analyses (TGA), scanning electron microscopy (SEM) and transmission electron microscopy (TEM).

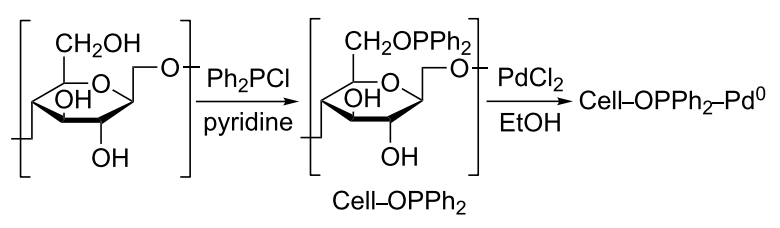

Scheme 1: Preparation of the Cell-OPPh $2-\mathrm{Pd}^{0}$.

The Pd loading was determined to be $0.33 \mathrm{mmol} / \mathrm{g}$ by ICP-AES. The IR spectra of Cell-OPPh 2 and Cell-OPPh $2-\mathrm{Pd}^{0}$ catalysts were recorded. The IR spectrum of Cell- $\mathrm{OPPh}_{2}$ contained absorption bands at $1029.9 \mathrm{~cm}^{-1}$ for C-O-P bond. This band is negatively shifted to $1028.8 \mathrm{~cm}^{-1}$ in the Cell- $\mathrm{OPPh}_{2}-\mathrm{Pd}^{0}$, indi- cating coordination of the phosphine atom with the palladium and further confirming the formation of a palladium complex on the surface of the polymer. Figure 1 shows the XRD pattern of the cellulose-supported palladium catalyst and the Cell- $\mathrm{OPPh}_{2}$ matrix. The Cell- $\mathrm{OPPh}_{2}$ displays a broad diffraction with $2 \theta$ ranging from $5^{\circ}$ to $35^{\circ}$, suggesting the amorphous structure of the polymeric scaffold. Besides the broad diffraction ascribed to the polymeric scaffold, other three diffraction peaks at $2 \theta$ of $40.0^{\circ}, 46.1^{\circ}$, and $67.5^{\circ}$ for the diffraction of the (111), (200) and (220) lattice planes of the face-centered cubic crystalline structure of the $\mathrm{Pd}$ nanoparticles are correspondingly clearly seen from the XRD pattern of Cell-OPPh $2-\mathrm{Pd}^{0}$ catalyst.

The thermal stability of Cell- $\mathrm{OPPh}_{2}-\mathrm{Pd}^{0}$ has a great effect on its catalytic activity and recyclability because the Suzuki-Miyaura reaction usually requires heating. TGA of the

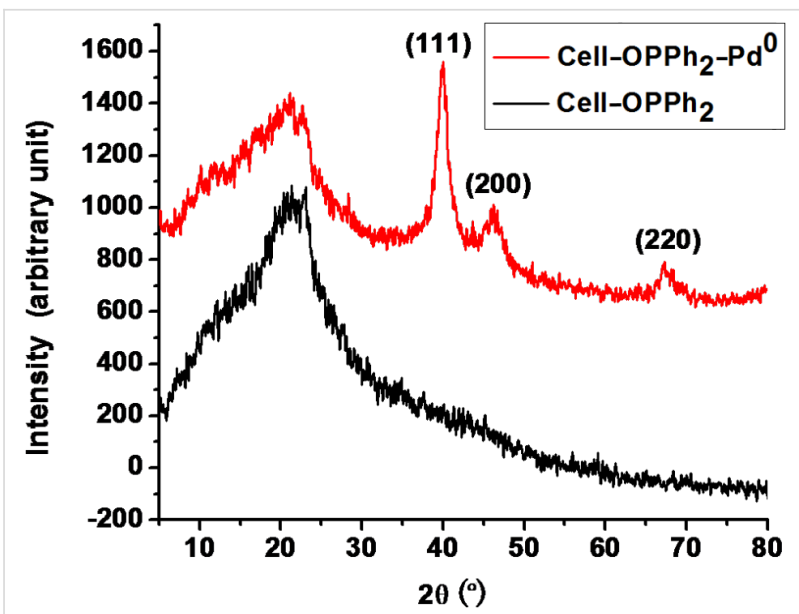

Figure 1: XRD pattern of the cellulose-supported palladium catalyst and $\mathrm{Cell}-\mathrm{OPPh}_{2}$ matrix.

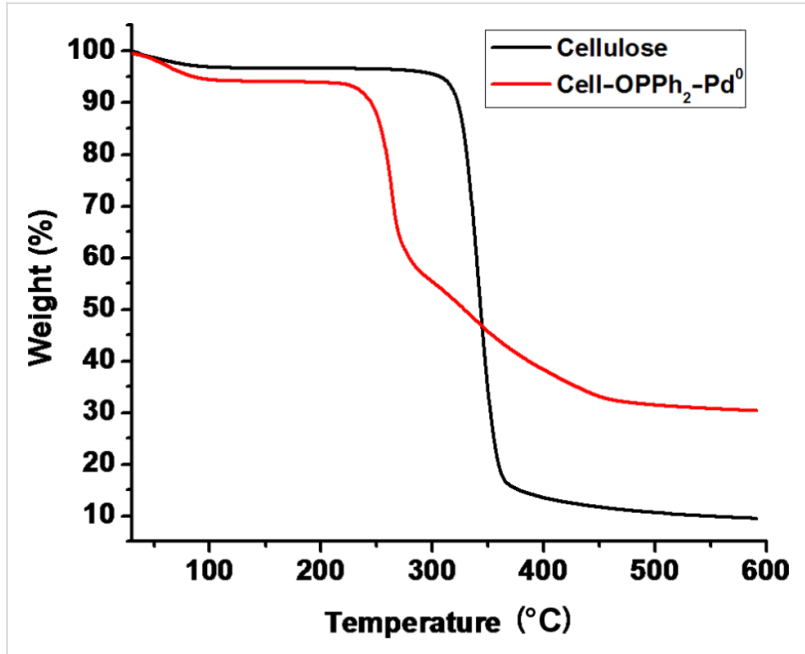

Figure 2: TG curve of the cellulose and Cell-OPPh${ }_{2}-\mathrm{Pd}^{0}$ under nitrogen flow. 

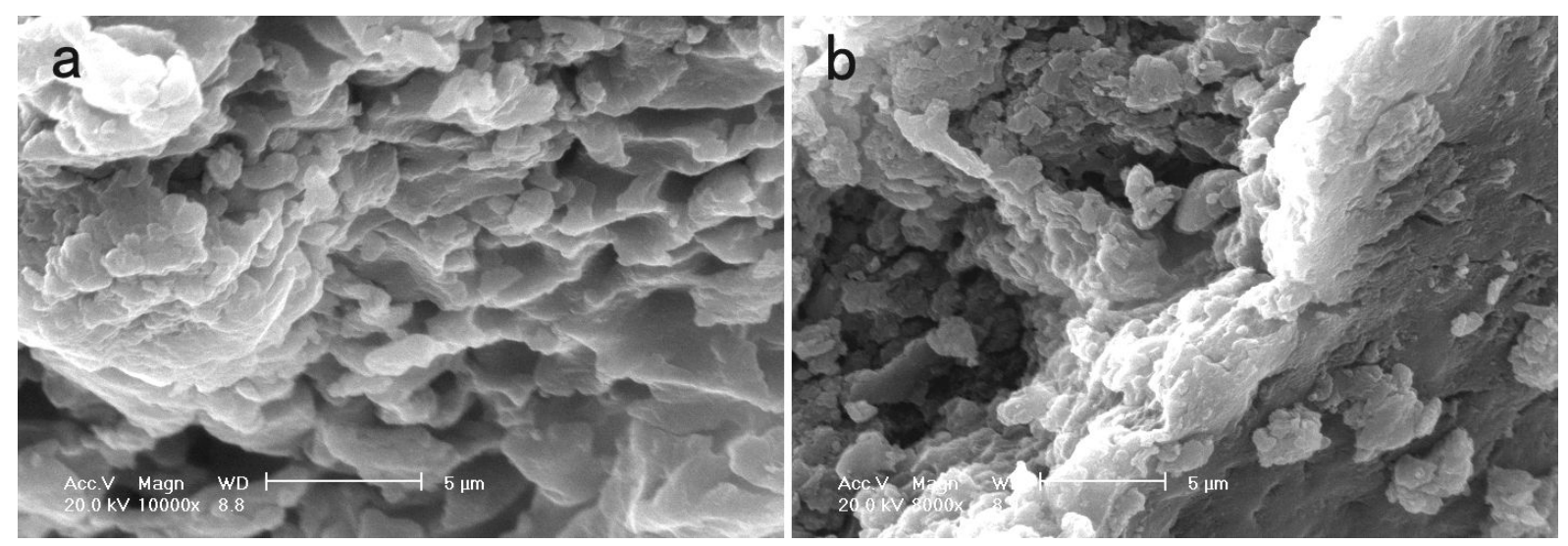

Figure 3: SEM images of the Cell-OPPh 2 (a) and the fresh catalyst Cell-OPPh${ }_{2}-\mathrm{Pd}^{0}$ (b).
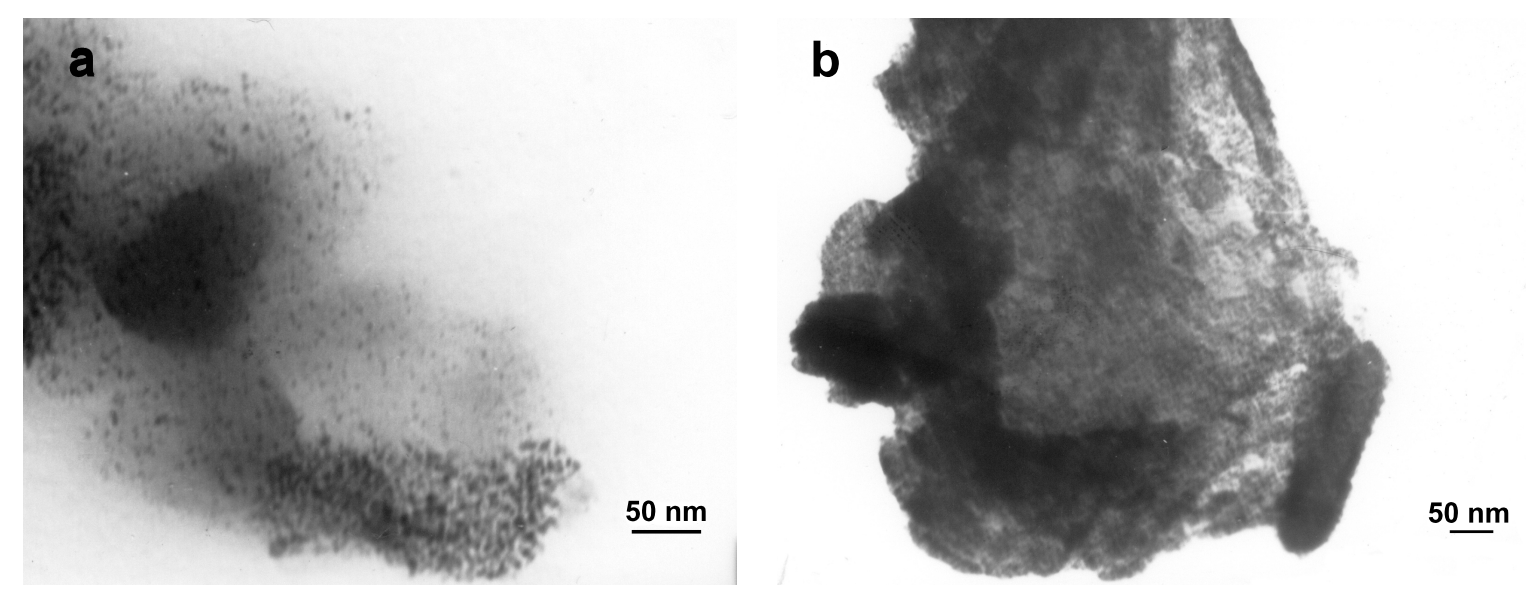

Figure 4: TEM image of the fresh Cell-OPPh${ }_{2}-\mathrm{Pd}^{0}$ catalyst (a) and the recovered catalyst after being reused six times (b) at the same magnification.

catalyst systems demonstrated high thermal stability with decomposition starting at around $250{ }^{\circ} \mathrm{C}$ under a nitrogen atmosphere. An initial weight loss of around $2.5 \%$ was observed up to $100{ }^{\circ} \mathrm{C}$, likely due to the release of adsorbed water (Figure 2).

The morphology of Cell-OPPh${ }_{2}-\mathrm{Pd}^{0}$ and Cell-OPPh${ }_{2}$ was studied by SEM and TEM. A clear change in morphology is observed after anchoring palladium onto the polymer support (Figure 3). The TEM image of the Cell- $\mathrm{OPPh}_{2}-\mathrm{Pd}^{0}$ catalyst shows that the average size of the nanopalladium particles is in the range of 4-15 nm (Figure 4a). The TEM image of the used catalyst indicates that the size and morphology of the nanopalladium has suffered slightly from agglomeration in the recovered catalyst after being reused six times (Figure 4b).

\section{Suzuki-Miyaura cross-coupling reactions}

To explore the efficiency of the diphenylphosphinite cellulosesupported nanopalladium catalyst, it was initially used in the Suzuki-Miyaura cross-coupling reaction, which is a versatile and a well studied method for the generation of $\mathrm{C}_{\mathrm{sp} 2}-\mathrm{C}_{\mathrm{sp} 2}$ bonds in organic synthesis. The influence of base, solvent and amount of catalyst on Suzuki-Miyaura cross-coupling were carefully examined with the reaction of 4-iodoanisole and

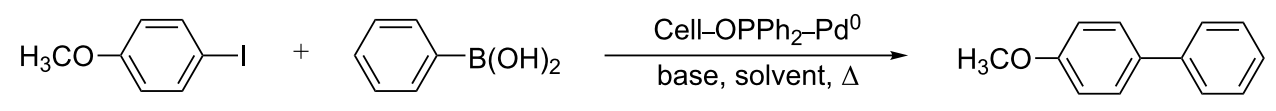


Table 1: Effect of base on the Suzuki-Miyaura cross-coupling reaction ${ }^{\mathrm{a}}$.

\begin{tabular}{llll} 
Entry & Base & Time $(\min )$ & Yield $^{\mathrm{b}}(\%)$ \\
\hline 1 & $\mathrm{~K}_{2} \mathrm{CO}_{3}$ & 15 & 93 \\
2 & $\mathrm{Na}_{2} \mathrm{CO}_{3}$ & 300 & 40 \\
3 & $\mathrm{Cs}_{2} \mathrm{CO}_{3}$ & 35 & 75 \\
4 & $\mathrm{NaOH}$ & 25 & 70 \\
5 & $\mathrm{~K}_{3} \mathrm{PO}_{4} \cdot 3 \mathrm{H}_{2} \mathrm{O}$ & 20 & 78 \\
6 & $\mathrm{CH}_{3} \mathrm{ONa}$ & 14 & 85 \\
7 & $\mathrm{KOH}_{8}$ & 60 & 40 \\
8 & $\mathrm{Na}_{3} \mathrm{PO}_{4} \cdot 12 \mathrm{H}_{2} \mathrm{O}$ & 120 & 85 \\
\hline
\end{tabular}

aReaction conditions: 4-iodoanisole $(1.0 \mathrm{mmol})$, phenylboronic acid $(1.2 \mathrm{mmol})$, base $(2.0 \mathrm{mmol})$, Cell-OPPh $2-\mathrm{Pd}^{0}(0.015 \mathrm{~g}, 0.005 \mathrm{mmol}$ of $\mathrm{Pd}$ ), and $5.0 \mathrm{~cm}^{3} 95 \%$ ethanol heating under reflux in air. blsolated yield based on 4-iodoanisole.

Table 2: Effect of solvent on the cross-coupling reaction ${ }^{a}$

\begin{tabular}{llll} 
Entry & Solvent & Time $(\min )$ & Yield $^{\mathrm{b}}(\%)$ \\
\hline 1 & $95 \%$ EtOH & 15 & 93 \\
2 & $\mathrm{EtOH}$ & 20 & 89 \\
3 & $\mathrm{CH}_{3} \mathrm{COCH}_{3}$ & 240 & 85 \\
4 & $\mathrm{CH}_{3} \mathrm{OH}$ & 25 & 82 \\
5 & $\mathrm{H}_{2} \mathrm{O}$ & 90 & 50 \\
6 & $\mathrm{DMF}_{7}$ & 300 & 45 \\
8 & $\mathrm{CH}_{3} \mathrm{CN}$ & 420 & 88 \\
8 & $\mathrm{DMSO}$ & 120 & 65 \\
\hline
\end{tabular}

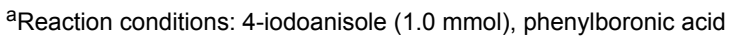
(1.2 mmol), $\mathrm{K}_{2} \mathrm{CO}_{3}(2.0 \mathrm{mmol})$, Cell-OPPh ${ }_{2}-\mathrm{Pd}^{0}(0.015 \mathrm{~g}, 0.005 \mathrm{mmol}$ of $\mathrm{Pd}$ ), and $5.0 \mathrm{~cm}^{3}$ solvent heating under reflux in air. bIsolated yield based on 4-iodoanisole.

phenylboronic acid chosen as the model reaction (Scheme 2). The results are summarized in Table 1, Table 2 and Table 3, respectively.

We found that using $\mathrm{K}_{2} \mathrm{CO}_{3}$ as the base in $95 \%$ ethanol at $78{ }^{\circ} \mathrm{C}$ gave the coupled product, biphenyl $3 \mathbf{e}$, in $93 \%$ yield after 15 min (Table 1, entry 1). The other inorganic bases such as $\mathrm{Na}_{2} \mathrm{CO}_{3}, \mathrm{Cs}_{2} \mathrm{CO}_{3}, \mathrm{NaOH}, \mathrm{K}_{3} \mathrm{PO}_{4} \cdot 3 \mathrm{H}_{2} \mathrm{O}, \mathrm{CH}_{3} \mathrm{ONa}, \mathrm{KOH}$ and $\mathrm{Na}_{3} \mathrm{PO}_{4} \cdot 12 \mathrm{H}_{2} \mathrm{O}$ were not as effective as $\mathrm{K}_{2} \mathrm{CO}_{3}$, and only afforded the coupling products in moderate to low yield (Table 1, entries 2-8). Among the screened bases, $\mathrm{K}_{2} \mathrm{CO}_{3}$
Table 3: Effect of the amount of Cell-OPPh $2-\mathrm{Pd}^{0}$ catalyst on the cross-coupling reaction ${ }^{\mathrm{a}}$.

\begin{tabular}{llll} 
Entry & $\begin{array}{l}\text { Amount of catalyst } \\
(\mathrm{mmol} P d)\end{array}$ & Time $(\mathrm{min})$ & Yield $^{\mathrm{b}}(\%)$ \\
\hline 1 & $0.15 \%$ & 14 & 89 \\
2 & $0.3 \%$ & 10 & 91 \\
3 & $0.5 \%$ & 10 & 94 \\
4 & $0.7 \%$ & 10 & 93 \\
5 & $0.9 \%$ & 10 & 94 \\
\hline
\end{tabular}

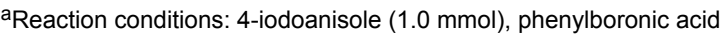
(1.2 mmol), $\mathrm{K}_{2} \mathrm{CO}_{3}(2.0 \mathrm{mmol})$, Cell-OPPh $2-\mathrm{Pd}^{0}$, and $5.0 \mathrm{~cm}^{3} 95 \%$ ethanol heating under reflux in air. ${ }^{\text {blsolated yield based on }}$ 4-iodoanisole. proved to be the best and was thus chosen as the base in the Suzuki-Miyaura reaction. From Table 2, we found that using 95\% ethanol as the solvent gave the highest yield, i.e., $93 \%$ (Table 2, entries 1-8). The results in Table 3 showed that the loading of catalyst has an effect on the yield. When $0.15 \mathrm{mmol} \%$ of the catalyst was used, the yield of the product reached $89 \%$. On increasing the amount of catalyst from 0.3 to $0.5 \mathrm{mmol} \%$, the reaction yield rose from $91 \%$ to $94 \%$. Further increasing the amount of catalyst had apparently no significant effect on the reaction yield. Therefore, $0.5 \mathrm{mmol} \%$ of the catalyst was enough to push the reaction to completion (Table 3 , entry 3 ).

To examine the scope for this coupling reaction, a variety of substituted aryl halides were coupled with different arylboronic acids in $95 \%$ ethanol in the presence of a catalytic amount of Cell- $\mathrm{OPPh}_{2}-\mathrm{Pd}^{0}(0.5 \mathrm{mmol} \% \mathrm{Pd})$ with $\mathrm{K}_{2} \mathrm{CO}_{3}$ as base (Scheme 3). The typical experimental results are summarized in Table 4.

The data presented in Table 4 show that the Cell- $-\mathrm{OPPh}_{2}-\mathrm{Pd}^{0}$ catalyst was highly effective for both aryl bromides and aryl iodides. Most of these reactions proceeded rapidly and were complete within $20 \mathrm{~min}$. The catalytic performance was excellent for substrates with electron-withdrawing groups (Table 4, entries 2, 3, 19, 20 and 22) and was only slightly lower for substrates with electron-donating groups (Table 4, entries 4 and 17), except for 4-iodoanisole and 4-bromoanisole (Table 4,<smiles>[R][R]1cccc([X])c1</smiles><smiles>C1CCC2CCCCC2CC1</smiles>

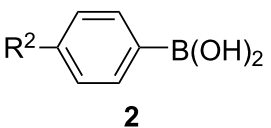

2
Cell-OPPh $-\mathrm{Pd}^{0}$ base, $95 \% \mathrm{EtOH}, \Delta$

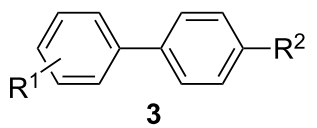


Table 4: The coupling reactions of aryl halides with various arylboronic acids ${ }^{\mathrm{a}}$.

\begin{tabular}{|c|c|c|c|c|c|}
\hline Entry & Aryl halide 1 & Arylboronic acid 2 & Time $(\min )$ & Yield ${ }^{b}(\%)$ & Product 3 \\
\hline 1 & $\mathrm{C}_{6} \mathrm{H}_{5} \mathrm{I}$ & $\mathrm{C}_{6} \mathrm{H}_{5} \mathrm{~B}(\mathrm{OH})_{2}$ & 20 & 85 & $3 a$ \\
\hline 2 & $4-\mathrm{NO}_{2}-\mathrm{C}_{6} \mathrm{H}_{4} \mathrm{I}$ & $\mathrm{C}_{6} \mathrm{H}_{5} \mathrm{~B}(\mathrm{OH})_{2}$ & 10 & 95 & $3 b$ \\
\hline 3 & $4-\mathrm{Cl}-\mathrm{C}_{6} \mathrm{H}_{4} \mathrm{I}$ & $\mathrm{C}_{6} \mathrm{H}_{5} \mathrm{~B}(\mathrm{OH})_{2}$ & 10 & 92 & $3 c$ \\
\hline 4 & $4-\mathrm{Me}-\mathrm{C}_{6} \mathrm{H}_{4} \mathrm{I}$ & $\mathrm{C}_{6} \mathrm{H}_{5} \mathrm{~B}(\mathrm{OH})_{2}$ & 15 & 85 & $3 d$ \\
\hline 5 & $4-\mathrm{MeO}-\mathrm{C}_{6} \mathrm{H}_{4} \mathrm{I}$ & $\mathrm{C}_{6} \mathrm{H}_{5} \mathrm{~B}(\mathrm{OH})_{2}$ & 15 & 93 & $3 e$ \\
\hline 6 & $4-\mathrm{MeO}-\mathrm{C}_{6} \mathrm{H}_{4} \mathrm{I}$ & $4-\mathrm{MeO}-\mathrm{C}_{6} \mathrm{H}_{4} \mathrm{~B}(\mathrm{OH})_{2}$ & 18 & 65 & $3 f$ \\
\hline 7 & 4-MeO- $\mathrm{C}_{6} \mathrm{H}_{4} \mathrm{I}$ & $4-\mathrm{Me}-\mathrm{C}_{6} \mathrm{H}_{4} \mathrm{~B}(\mathrm{OH})_{2}$ & 15 & 95 & $3 g$ \\
\hline 8 & $4-\mathrm{MeO}-\mathrm{C}_{6} \mathrm{H}_{4} \mathrm{I}$ & $4-\mathrm{Cl}-\mathrm{C}_{6} \mathrm{H}_{4} \mathrm{~B}(\mathrm{OH})_{2}$ & 15 & 93 & $3 h$ \\
\hline 9 & $4-\mathrm{MeO}-\mathrm{C}_{6} \mathrm{H}_{4} \mathrm{I}$ & $4-\mathrm{F}-\mathrm{C}_{6} \mathrm{H}_{4} \mathrm{~B}(\mathrm{OH})_{2}$ & 15 & 94 & $3 \mathbf{i}$ \\
\hline 10 & $4-\mathrm{MeO}-\mathrm{C}_{6} \mathrm{H}_{4} \mathrm{I}$ & $4-\mathrm{CHO}-\mathrm{C}_{6} \mathrm{H}_{4} \mathrm{~B}(\mathrm{OH})_{2}$ & 15 & 96 & $3 \mathbf{j}$ \\
\hline 11 & $4-\mathrm{NO}_{2}-\mathrm{C}_{6} \mathrm{H}_{4} \mathrm{I}$ & $4-\mathrm{MeO}-\mathrm{C}_{6} \mathrm{H}_{4} \mathrm{~B}(\mathrm{OH})_{2}$ & 15 & 98 & $3 k$ \\
\hline 12 & $4-\mathrm{NO}_{2}-\mathrm{C}_{6} \mathrm{H}_{4} \mathrm{I}$ & $4-\mathrm{Me}-\mathrm{C}_{6} \mathrm{H}_{4} \mathrm{~B}(\mathrm{OH})_{2}$ & 8 & 68 & 31 \\
\hline 13 & $4-\mathrm{NO}_{2} \mathrm{C}_{6} \mathrm{H}_{4} \mathrm{I}$ & $4-\mathrm{Cl}-\mathrm{C}_{6} \mathrm{H}_{4} \mathrm{~B}(\mathrm{OH})_{2}$ & 15 & 86 & $3 m$ \\
\hline 14 & $4-\mathrm{NO}_{2}-\mathrm{C}_{6} \mathrm{H}_{4} \mathrm{I}$ & $4-\mathrm{F}-\mathrm{C}_{6} \mathrm{H}_{4} \mathrm{~B}(\mathrm{OH})_{2}$ & 15 & 96 & $3 n$ \\
\hline 15 & $4-\mathrm{NO}_{2}-\mathrm{C}_{6} \mathrm{H}_{4} \mathrm{I}$ & $4-\mathrm{CHO}-\mathrm{C}_{6} \mathrm{H}_{4} \mathrm{~B}(\mathrm{OH})_{2}$ & 10 & 91 & 30 \\
\hline 16 & $\mathrm{C}_{6} \mathrm{H}_{5} \mathrm{Br}$ & $\mathrm{C}_{6} \mathrm{H}_{5} \mathrm{~B}(\mathrm{OH})_{2}$ & 15 & 63 & $3 a$ \\
\hline 17 & 4-Me- $\mathrm{C}_{6} \mathrm{H}_{4} \mathrm{Br}$ & $\mathrm{C}_{6} \mathrm{H}_{5} \mathrm{~B}(\mathrm{OH})_{2}$ & 30 & 60 & $3 d$ \\
\hline 18 & $4-\mathrm{MeO}-\mathrm{C}_{6} \mathrm{H}_{4} \mathrm{Br}$ & $\mathrm{C}_{6} \mathrm{H}_{5} \mathrm{~B}(\mathrm{OH})_{2}$ & 25 & 75 & $3 e$ \\
\hline 19 & $4-\mathrm{NO}_{2}-\mathrm{C}_{6} \mathrm{H}_{4} \mathrm{Br}$ & $\mathrm{C}_{6} \mathrm{H}_{5} \mathrm{~B}(\mathrm{OH})_{2}$ & 15 & 96 & $3 b$ \\
\hline 20 & $3-\mathrm{NO}_{2}-\mathrm{C}_{6} \mathrm{H}_{4} \mathrm{Br}$ & $\mathrm{C}_{6} \mathrm{H}_{5} \mathrm{~B}(\mathrm{OH})_{2}$ & 10 & 93 & $3 p$ \\
\hline 21 & $4-\mathrm{Br}-\mathrm{C}_{6} \mathrm{H}_{5} \mathrm{Br}$ & $\mathrm{C}_{6} \mathrm{H}_{5} \mathrm{~B}(\mathrm{OH})_{2}$ & 50 & 48 & $3 q$ \\
\hline 22 & $4-\mathrm{MeO}_{2} \mathrm{C}-\mathrm{C}_{6} \mathrm{H}_{4} \mathrm{Br}$ & $\mathrm{C}_{6} \mathrm{H}_{5} \mathrm{~B}(\mathrm{OH})_{2}$ & 20 & 98 & $3 r$ \\
\hline 23 & $4-\mathrm{NO}_{2}-\mathrm{C}_{6} \mathrm{H}_{4} \mathrm{Cl}$ & $\mathrm{C}_{6} \mathrm{H}_{5} \mathrm{~B}(\mathrm{OH})_{2}$ & $12 \mathrm{~h}$ & 23 & $3 b$ \\
\hline
\end{tabular}

${ }^{a}$ Reaction conditions: aryl halide $(1.0 \mathrm{mmol})$, arylboronic acid $(1.2 \mathrm{mmol}), \mathrm{K}_{2} \mathrm{CO}_{3}(2.0 \mathrm{mmol})$, Cell-OPPh$-\mathrm{Pd}^{0}(0.015 \mathrm{~g}, 0.005 \mathrm{mmol}$ of Pd), and $5.0 \mathrm{~cm}^{3} 95 \%$ ethanol heating under reflux in air. ${ }^{b}$ Isolated yield based on aryl halide.

entries 5 and 18). As expected, the reactivity of aryl bromides was slightly lower than that of the corresponding aryl iodides and in these cases a prolonged time was required. The reaction of aryl chlorides with arylboronic acids was sluggish and gave only small amounts of products in acceptable times.

The reusability of the supported catalyst is a very important theme from the standpoint of green chemistry and for its suitability for commercial applications. Finally, we explored the reusability of the Cell- $\mathrm{OPPh}_{2}-\mathrm{Pd}^{0}$ catalyst again with the reaction of 4-iodoanisole with phenylboronic acid as the model reaction. After the first run, the catalyst was filtered and extensively washed with ethanol and dried in vacuo. Then the catalyst was reused directly under the same conditions mentioned above. The results are shown in Figure 5.

It can be seen from the results that the catalyst could be reused up to six times whilst still retaining good catalytic activity. Characterization of the reused catalysts by TEM showed that the slight agglomeration of the palladium nanoparticles had no apparently effect on its catalytic performance (Figure 4).

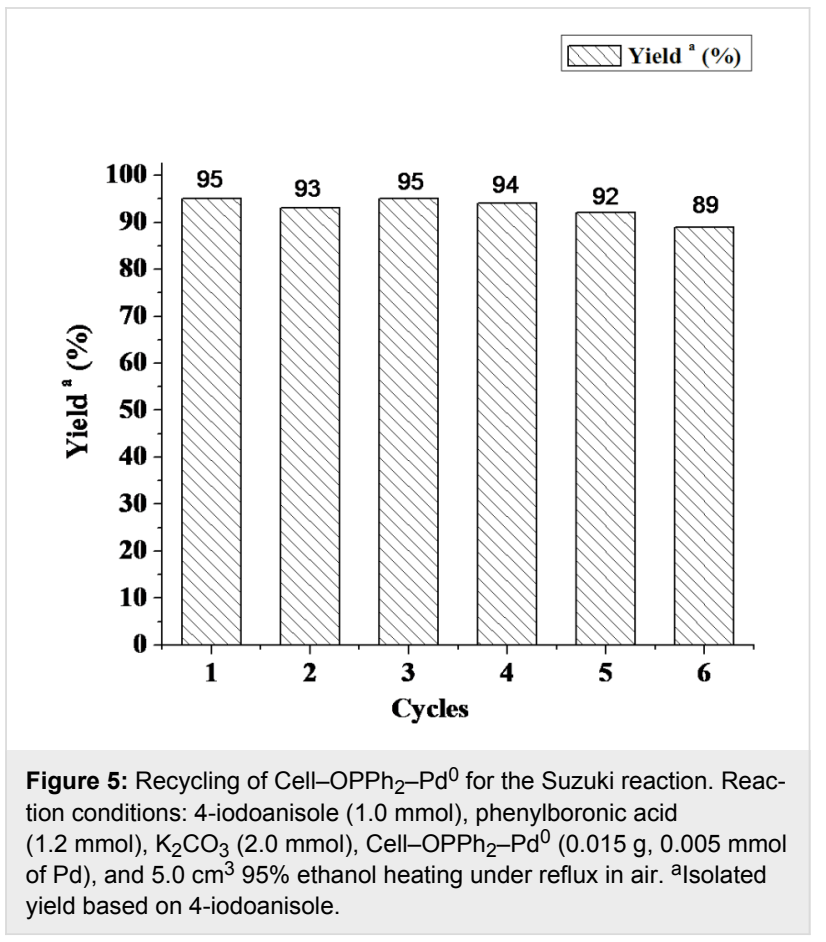




\section{Conclusion}

Nanopalladium immobilized on the surface of Cell- $\mathrm{OPPh}_{2}$ has high catalytic activity in Suzuki-Miyaura cross-coupling reactions in $95 \%$ aqueous ethanol under atmospheric conditions. The catalyst can be easily separated and recovered from the reaction mixture by filtration and reused up to six times without any noticeable loss of activity. This simple procedure, coupled with the easy recovery and reusability of the catalyst is expected to contribute to the development of chemical processes and products.

\section{Experimental General}

Melting points were measured on an Electrothermal X6 microscopic digital melting point apparatus. IR spectra were recorded on a Bruker Equinox-55 spectrometer as $\mathrm{KBr}$ pellets. ${ }^{1} \mathrm{H}$ NMR spectra were obtained with a $300 \mathrm{MHz}$ Bruker Avance instrument with $\mathrm{CDCl}_{3}$ as solvent and TMS as internal standard. Elemental analyses were performed on a Perkin-Elmer EA2400II elemental analyzer. The elemental palladium content of the polymeric catalysts was determined by Perkin-Elmer Optima 2000DV inductively coupled plasma (ICP) spectroscopy. Scanning electron microscopy (SEM) was performed with a Philips XL 30ESEM instrument. Transmission electron microscopy (TEM) was performed with a Philips Tecnai instrument operating at $40-100 \mathrm{kV}$. The chemicals were obtained from commercial sources and used as received.

\section{Preparation of diphenylphosphinite cellulose $($ Cell-OPPh 2$)$}

A mixture of cellulose $(3.0 \mathrm{~g})$ and dry pyridine $\left(120 \mathrm{~cm}^{3}\right)$ in a round-bottomed flask was vigorous stirred at $80-90{ }^{\circ} \mathrm{C}$ for $30 \mathrm{~min}$. After being cooled to room temperature, diphenylchlorophosphine $\left(12 \mathrm{~cm}^{3}\right)$ was added to the mixture and the reaction mixture stirred at room temperature for $5 \mathrm{~d}$. The reaction mixture was filtered and the solid obtained washed with a large volume of ethanol and dried under vacuum at $60{ }^{\circ} \mathrm{C}$ to give white Cell- $\mathrm{OPPh}_{2}$.

\section{Preparation of Cell-OPPh $2-\mathrm{Pd}^{0}$ complex}

Cell- $\mathrm{OPPh}_{2}(2.0 \mathrm{~g})$ was added to a solution of $\mathrm{PdCl}_{2}(0.16 \mathrm{~g}$, $0.9 \mathrm{mmol})$ in $95 \%$ ethanol $\left(30 \mathrm{~cm}^{3}\right)$. The mixture was heated under reflux for $24 \mathrm{~h}$, allowed to cool and filtered. The resulting product was washed successively with ethanol $\left(3 \times 25 \mathrm{~cm}^{3}\right)$ and $\mathrm{Et}_{2} \mathrm{O}\left(3 \times 25 \mathrm{~cm}^{3}\right)$ and dried under vacuum at $60{ }^{\circ} \mathrm{C}$ to give the dark gray polymeric palladium $(0)$ complex $\left(\right.$ Cell- $\left.\mathrm{OPPh}_{2}-\mathrm{Pd}^{0}\right)$.

\section{General procedure for the Suzuki-Miyaura cross- coupling reaction}

In a typical experiment, the Cell-OPPh $2-\mathrm{Pd}^{0}$ catalyst $(0.005 \mathrm{mmol}$ of $\mathrm{Pd})$ was added to a mixture of aryl halide
(1.0 mmol), arylboronic acid $(1.2 \mathrm{mmol})$, and $\mathrm{K}_{2} \mathrm{CO}_{3}$ ( $2.0 \mathrm{mmol})$ in $95 \%$ ethanol $\left(5 \mathrm{~cm}^{3}\right)$, and the reaction mixture was stirred and heated under reflux. After the reaction was judged to be complete by TLC analysis, the catalyst was removed by filtration, washed with ethanol $\left(3 \times 4 \mathrm{~cm}^{3}\right)$ and dried under vacuum for the next run. The organic fractions were then concentrated on a rotary evaporator to obtain the desired biaryl in excellent yield. The crude products were further purified by recrystallization. All of the products (3a-3r) are known compounds and their data was identical to that reported in literature. The data of some products are as follows:

3b: Mp 113-114 ${ }^{\circ} \mathrm{C} .{ }^{1} \mathrm{H}$ NMR $\left(\mathrm{CDCl}_{3}, 300 \mathrm{MHz}\right) \delta 8.30(\mathrm{~d}, J=$ $8.7 \mathrm{~Hz}, 2 \mathrm{H}, \mathrm{Ar}-\mathrm{H}), 7.74(\mathrm{~d}, J=8.7 \mathrm{~Hz}, 2 \mathrm{H}, \mathrm{Ar}-\mathrm{H}), 7.62(\mathrm{t}, J=$ $7.5 \mathrm{~Hz}, 2 \mathrm{H}, \mathrm{Ar}-\mathrm{H}), 7.50-7.45$ (m, 3H, Ar-H); IR (KBr) v 3076, $1595,1541,1347,1105,854,741,700 \mathrm{~cm}^{-1}$.

3e: $\mathrm{Mp} 86-87{ }^{\circ} \mathrm{C} .{ }^{1} \mathrm{H}$ NMR $\left(\mathrm{CDCl}_{3}, 300 \mathrm{MHz}\right) \delta 7.56(\mathrm{~d}, J=$ $7.3 \mathrm{~Hz}, 4 \mathrm{H}, \mathrm{Ar}-\mathrm{H}), 7.44$ (d, $J=7.8 \mathrm{~Hz}, 2 \mathrm{H}, \mathrm{Ar}-\mathrm{H}), 7.30$ (d, $J=$ $7.2 \mathrm{~Hz}, 1 \mathrm{H}, \mathrm{Ar}-\mathrm{H}), 6.99$ (d, $J=6.7 \mathrm{~Hz}, 2 \mathrm{H}, \mathrm{Ar}-\mathrm{H}), 3.85$ (s, 3H, $\left.\mathrm{CH}_{3} \mathrm{O}\right)$; IR $(\mathrm{KBr}) \vee 2961,1606,1522,1488,1251,1201,1036$, $833,760,699 \mathrm{~cm}^{-1}$.

3k: Mp $105-107{ }^{\circ} \mathrm{C} .{ }^{1} \mathrm{H}$ NMR $\left(\mathrm{CDCl}_{3}, 300 \mathrm{MHz}\right) \delta 8.23(\mathrm{~d}, J=$ $8.9 \mathrm{~Hz}, 2 \mathrm{H}, \mathrm{Ar}-\mathrm{H}), 7.67$ (d, $J=7.8 \mathrm{~Hz}, 2 \mathrm{H}, \mathrm{Ar}-\mathrm{H}), 7.56$ (d, $J=$ $7.2 \mathrm{~Hz}, 2 \mathrm{H}, \mathrm{Ar}-\mathrm{H}), 7.00$ (d, $J=6.7 \mathrm{~Hz}, 2 \mathrm{H}, \mathrm{Ar}-\mathrm{H}), 3.86$ (s, 3H, $\left.\mathrm{CH}_{3} \mathrm{O}\right)$; IR (KBr) v 2930, 2835, 1593, 1508, 1344, 1252, 1187 , $1108,1016,857,757,697 \mathrm{~cm}^{-1}$.

3n: $\mathrm{Mp} 122-125{ }^{\circ} \mathrm{C} .{ }^{1} \mathrm{H}$ NMR $\left(\mathrm{CDCl}_{3}, 300 \mathrm{MHz}\right) \delta 8.29(\mathrm{~d}, J=$ $8.3 \mathrm{~Hz}, 2 \mathrm{H}, \mathrm{Ar}-\mathrm{H}), 7.69$ (d, $J=8.8 \mathrm{~Hz}, 2 \mathrm{H}, \mathrm{Ar}-\mathrm{H}), 7.62-7.60$ $(\mathrm{m}, 2 \mathrm{H}), 7.21-7.19(\mathrm{~m}, 2 \mathrm{H})$; IR $(\mathrm{KBr}) \vee 3075,1599,1518$, $1348,1233,1113,853,756,728 \mathrm{~cm}^{-1}$.

\section{Supporting Information}

\section{Supporting Information File 1}

IR for catalyst and selected products. [http://www.beilstein-journals.org/bjoc/content/ supplementary/1860-5397-7-48-S1.pdf]

\section{Supporting Information File 2}

${ }^{1} \mathrm{H}$ NMR spectra for selected products. [http://www.beilstein-journals.org/bjoc/content/ supplementary/1860-5397-7-48-S2.pdf]

\section{Acknowledgements}

We are grateful to the National Natural Science Foundation of China (Nos. 21072077 and 20672046), the Guangdong Natural Science Foundation (Nos. 10151063201000051 and 
8151063201000016) and the Guangzhou Science \& Technology Project (2010Y1-C511) for financial support.

\section{References}

1. Miyaura, N.; Suzuki, A. Chem. Rev. 1995, 95, 2457-2483. doi:10.1021/cr00039a007

2. Phan, N. T. S.; Van der Sluys, M.; Jones, C. W. Adv. Synth. Catal. 2006, 348, 609-679. doi:10.1002/adsc.200505473

3. Farina, V. Adv. Synth. Catal. 2004, 346, 1553-1582. doi:10.1002/adsc.200404178

4. Stanforth, S. P. Tetrahedron 1998, 54, 263-303. doi:10.1016/S0040-4020(97)10233-2

5. Hassan, J.; Sévignon, M.; Gozzi, C.; Schulz, E.; Lemaire, M. Chem. Rev. 2002, 102, 1359-1470. doi:10.1021/cr000664r

6. Goldnger, M. B.; Crawford, K. B.; Swager, T. M. J. Am. Chem. Soc. 1997, 119, 4578-4593. doi:10.1021/ja9642673

7. Nobre, S. M.; Wolke, S. I.; da Rosa, R. G.; Monteiro, A. L. Tetrahedron Lett. 2004, 45, 6527-6530. doi:10.1016/j.tetlet.2004.04.198

8. Stevens, P. D.; Li, G.; Fan, J. D.; Yen, M.; Gao, Y. Chem. Commun. 2005, 4435-4437. doi:10.1039/b505424a

9. Corma, A.; García, H.; Leyva, A. J. Catal. 2006, 240, 87-99. doi:10.1016/j.jcat.2006.03.007

10. Zapf, A.; Ehrentraut, A.; Beller, M. Angew. Chem., Int. Ed. 2000, 39, 4153-4155. doi:10.1002/1521-3773(20001117)39:22<4153::AID-ANIE4153>3.0.CO ;2-T

11. Walker, S. D.; Barder, T. E.; Martinelli, J. R.; Buchwald, S. L. Angew. Chem., Int. Ed. 2004, 43, 1871-1876. doi:10.1002/anie.200353615

12. Wolf, C.; Ekoue-Kovi, K. Eur. J. Org. Chem. 2006, 1917-1925. doi:10.1002/ejoc.200500843

13. O'Brien, C. J.; Kantchev, E. A. B.; Valente, C.; Hadei, N.; Chass, G. A.; Lough, A.; Hopkinson, A. C.; Organ, M. G. Chem.-Eur. J. 2006, 12, 4743-4748. doi:10.1002/chem.200600251

14. Brendgen, T.; Frank, M.; Schatz, J. Eur. J. Org. Chem. 2006, 10, 2378-2383. doi:10.1002/ejoc.200500943

15. Özdemir, I.; Yaşar, S.; Demir, S.; Çetinkaya, B. Heteroat. Chem. 2005, 16, 557-561. doi:10.1002/hc.20140

16. Dai, W.-M.; Zhang, Y. Tetrahedron Lett. 2005, 46, 1377-1381. doi:10.1016/j.tetlet.2004.12.133

17. Chen, W.; Li, R.; Han, B.; Li, B.-J.; Chen, Y.-C.; Wu, Y.; Ding, L.-S.; Yang, D. Eur. J. Org. Chem. 2006, 5, 1177-1184. doi:10.1002/ejoc.200500644

18. Kovala-Demertzi, D.; Kourkoumelis, N.; Derlat, K.; Michalak, J.; Andreadaki, F. J.; Kostas, I. D. Inorg. Chim. Acta 2008, 361, 1562-1565. doi:10.1016/j.ica.2007.09.038

19. Uozumi, Y. Top. Curr. Chem. 2004, 242, 77-112. doi:10.1007/b96874

20. Nan, G.; Ren, F.; Luo, M. Beilstein J. Org. Chem. 2010, 6, No. 70. doi:10.3762/bjoc.6.70

21. Yin, L.; Liebscher, J. Chem. Rev. 2007, 107, 133-173. doi:10.1021/cr0505674

22. Lamblin, M.; Hardy-Nassar, L.; Hierso, J.-C.; Fouquet, E.; Felpin, F.-X. Adv. Synth. Catal. 2010, 352, 33-79. doi:10.1002/adsc.200900765

23. Stambuli, J. P.; Kuwano, R.; Hartwig, J. F. Angew. Chem., Int. Ed. 2002, 41, 4746-4748. doi:10.1002/anie.200290036

24. Navarro, O.; Kaur, H.; Mahjoor, P.; Nolan, S. P. J. Org. Chem. 2004 69, 3173-3180. doi:10.1021/jo035834p
25. Altenhoff, G.; Goddard, R.; Lehmann, C. W.; Glorius, F. J. Am. Chem. Soc. 2004, 126, 15195-15201. doi:10.1021/ja045349r

26. Cho, J. K.; Najman, R.; Dean, T. W.; Ichihara, O.; Muller, C.; Bradley, M. J. Am. Chem. Soc. 2006, 128, 6276-6277. doi:10.1021/ja057480k

27. Choudary, B. M.; Madhi, S.; Chowdary, N. S.; Kantam, M. L.; Sreedhar, B. J. Am. Chem. Soc. 2002, 124, 14127-14136. doi:10.1021/ja026975w

28. Reddy, K. R.; Kumar, N. S.; Reddy, P. S.; Streedhar, B.; Kantam, M. L. J. Mol. Catal. A: Chem. 2006, 252, 12-16. doi:10.1016/j.molcata.2006.02.024

29. Gronnow, M. J.; Luque, R.; Macquarrie, D. J.; Clark, J. H. Green Chem. 2005, 7, 552-557. doi:10.1039/b501130b

30. Song, D.; Wen, B. Y. J. Mol. Catal. A: Chem. 2008, 280, 20-23. doi:10.1016/j.molcata.2007.10.017

31. Corma, A.; Gracia, H.; Leyva, A. J. Mol. Catal. A: Chem. 2005, 230, 97-105. doi:10.1016/j.molcata.2004.11.030

32. Cirtiu, C. M.; Dunlop-Brière, A. F. D.; Moores, A. Green Chem. 2011, 13, 288-291. doi:10.1039/c0gc00326c

33. Xu, Y.; Zhang, L.; Cui, Y. J. Appl. Polym. Sci. 2008, 110, 2996-3000. doi:10.1002/app.28655

34. Quignard, F.; Choplin, A. Chem. Commun. 2001, 21-22. doi:10.1039/b007776n

35. Clarke, M. L.; France, M. B.; Fuentes, J. A.; Milton, E. J.; Roff, G. J. Beilstein J. Org. Chem. 2007, 3, No. 18. doi:10.1186/1860-5397-3-18

36. Iranpoor, N.; Firouzabadi, H.; Azadi, R. Eur. J. Org. Chem. 2007, 2197-2201. doi:10.1002/ejoc.200601021

37. Iranpoor, N.; Firouzabadi, H.; Azadi, R. J. Organomet. Chem. 2008, 693, 2469-2472. doi:10.1016/j.jorganchem.2008.04.037

38. Firouzabadi, H.; Iranpoor, N.; Gholinejad, M. Tetrahedron 2009, 65, 7079-7084. doi:10.1016/j.tet.2009.06.081

39. Kostas, I. D.; Steele, B. R.; Terzis, A.; Amosova, S. V. Tetrahedron 2003, 59, 3467-3473. doi:10.1016/S0040-4020(03)00474-5

40. Cheng, Y.-H.; Weng, C.-M.; Hong, F.-E. Tetrahedron 2007, 63, 12277-12285. doi:10.1016/j.tet.2007.09.070

41. Zhang, B.-S.; Wang, C.; Gong, J.-F.; Song, M.-P. J. Organomet. Chem. 2009, 694, 2555-2561. doi:10.1016/j.jorganchem.2009.04.002

42. Tamami, B.; Kolahdoozan, M. Tetrahedron Lett. 2004, 45, 1535-1537. doi:10.1016/j.tetlet.2003.12.014

43. Bergbreiter, D. E.; Osburn, P. L.; Wilson, A.; Sink, E. M. J. Am. Chem. Soc. 2000, 122, 9058-9064. doi:10.1021/ja001708g

44. Tamami, B.; Ghasemi, S. J. Mol. Catal. A: Chem. 2010, 322, 98-105. doi:10.1016/j.molcata.2010.02.025 


\section{License and Terms}

This is an Open Access article under the terms of the Creative Commons Attribution License

(http://creativecommons.org/licenses/by/2.0), which permits unrestricted use, distribution, and reproduction in any medium, provided the original work is properly cited.

The license is subject to the Beilstein Journal of Organic Chemistry terms and conditions:

(http://www.beilstein-journals.org/bjoc)

The definitive version of this article is the electronic one which can be found at:

doi:10.3762/bjoc. 7.48 